\title{
Lithologic and topographic controls on weathering in temperate coastal rainforest, Southeast Alaska
}

ASHLEE DERE ${ }^{1}$, DAVID D'AMORE, REBECCA LYBRAND $^{3}$, DIOGO SPINOLA ${ }^{4}$, JENNIFER FEDENKO ${ }^{5}$, AND TIMOTHY WHITE ${ }^{6}$

${ }^{1}$ University of Nebraska at Omaha, adere@unomaha.edu

${ }^{2}$ USDA Pacific Northwest Research Station, Juneau, AK, david.v.damore@usda.gov

${ }^{3}$ Oregon State University, Corvallis, OR, rebecca.lybrand@oregonstate.edu

${ }^{4}$ University of Alaska Fairbanks, Fairbanks, , dspinola@alaska.edu

${ }^{5}$ Oregon State University, Corvallis, OR, jennifer.fedenko@oregonstate.edu

${ }^{6}$ Pennsylvania State University, tswhite@psu.edu

The perhumid climate in coastal temperate rainforests enhances mineral weathering and soil carbon storage that supports terrestrial and aquatic ecosystems, yet the soils and weathering processes remain understudied. Here we examine the interplay of climate, lithology, and topography on weathering processes in the Héen Latinee Experimental Forest near Juneau, Alaska to improve our ability to predict soil formation in these complex landscapes. Soil pedons were described and sampled by morphologic horizon to bedrock from i) ridgetop and midslope topographic positions; ii) the same elevations on north- or south-facing slopes; and iii) across three distinct lithologies (intrusive igneous, metamorphic, sedimentary). Soils along ridgetop positions were shallower and less developed than those at the midslope, where colluvial deposition and intense leaching promoted thick and welldeveloped Spodosols even on steep slopes; differences in soil thickness and development among lithologies were less evident (1-1.5 m). Soils on sedimentary rocks were more weathered compared to metamorphic and igneous rocks, and on south- vs. north-facing slopes. 
This abstract is too long to be accepted for publication.

Please revise it so that it fits into the column on one page. 